\title{
Low Absorption Reticulocyte Measurement
}

National Cancer Institute

\section{Source}

National Cancer Institute. Low Absorption Reticulocyte Measurement. NCI Thesaurus. Code C116190.

The determination of the amount of low absorption reticulocytes present in a sample. 